\title{
PHYSICAL-MECHANICAL PROPERTIES OF $\gamma$-IRRADIATED SiC CERAMICS FOR RADIOACTIVE WASTES IMMOBILIZATION
}

\author{
K. Lobach ${ }^{1 *}$, S. Sayenko1, (DV. Shkuropatenko', (D) Voyevodin ${ }^{1,3}$, (D) A. Zykova ${ }^{1}$, \\ E. Bereznyak ${ }^{1}$, Y. Hodyreva ${ }^{1}$, S. Bykanov ${ }^{2}$, A. Bykov ${ }^{2}$, iD. Tovazhnyanskyy ${ }^{2}$ \\ ${ }^{I}$ National Science Center Kharkov Institute of Physics and Technology, 61108, Kharkov, Ukraine, \\ ${ }^{2}$ National Technical University "Kharkiv Polytechnic Institute”, 61002, Kharkov, Ukraine, \\ ${ }^{3}$ V.N. Karazin Kharkiv National University, 61022, Kharkiv, Ukraine \\ *E-mail:lobach0709@gmail.com \\ Received 11 October 2018, accepted 29 November 2018
}

The interest in silicon carbide (SiC-based) ceramics and composites as matrix material for nuclear waste immobilization is grown up. Long-term chemical durability and radiation resistance of $\mathrm{SiC}$ are important factors for radionuclides immobilization. Advantages of SiC-based ceramics as structural materials in nuclear applications are the high-temperature properties, high density and reduced neutron activation. The use of radiation resistant materials is a strong requirement for safe and environmentally beneficial energy system. The SiC ceramics stability under irradiation for temperatures up to $1273 \mathrm{~K}$ is also very important for nuclear power applications. The $\mathrm{SiC}$ matrices doped by additives of $\mathrm{Cr}$, Si were fabricated using High Speed Hot Pressing Method. Additives content was in the range from 0.5 to $3 \mathrm{wt} \%$. Microstructural characteristics of silicon carbide ceramics were analyzed by X-ray diffraction (XRD), scanning electron microscopy (SEM), energy-dispersive X-ray spectroscopy (EDX), and infra-red spectroscopy (IR) methods. The results of microcracking under indentation conditions were revealed the lack of cracks in the $\mathrm{SiC}$ ceramics with $\mathrm{Cr}$ additives before and after irradiation process. In addition, it was demonstrated that samples of $\mathrm{SiC}$ with alloying additives $\mathrm{Cr}$ and $\mathrm{Si}$ possess high mechanical parameters under $\gamma$-irradiation process. The strength of ceramics increases with the uniform and finegrained structure formation. The modification of phase composition and mechanical properties of the $\mathrm{SiC}$ ceramics with $\mathrm{Cr}$ and $\mathrm{Si}$ additives under $\gamma$-irradiation were analyzed for further development of radiation resistant and matrix materials for radioactive wastes immobilization.

KEYWORDS: silicon carbide, irradiation, physical-mechanical properties, nuclear waste immobilization, microstructural characteristics.

\section{ФІЗИКО-МЕХАНІЧНІ ВЛАСТИВОСТІ $\gamma$-ОПРОМІНЕННОЙ $\mathrm{SiC} \mathrm{КЕРАМІКИ} \mathrm{ДЛЯ} \mathrm{ІММОБІЛІЗАЦІї}$ РАДІОАКТИВНИХ ВІДХОДІВ \\ К.В. Лобач ${ }^{1}$, С.Ю. Саєнко ${ }^{1}$ В.А. Шкуропатенко ${ }^{1}$ В.М. Воєводін ${ }^{13}$, Г.В. Зикова ${ }^{1}$, О.П. Березняк ${ }^{1}$ Ю.С. Ходирєва ${ }^{1}$, С.М. Биканов ${ }^{2}$, А.О. Биков ${ }^{2}$, Л.Л. Товажнянський ${ }^{2}$ ${ }^{1}$ ННЦ Харківський фізико-технічний інститут, 61108, Харків, Україна \\ ${ }^{2}$ НТУ «Харківський політехнічний інститут», 61002, Харків, Украӥна \\ ${ }^{3}$ Харківський національний університет імені В.Н. Каразіна, 61022, Харків, Украӥна}

Інтерес до карбіду кремнію, кераміки та композитів на основі $\mathrm{SiC}$ як матричного матеріалу для іммобілізації ядерних відходів зростає. Довготривала хімічна та радіаційна стійкість $\mathrm{SiC} \epsilon$ важливими факторами для іммобілізації радіонуклідів. Перевагами кераміки на основі $\mathrm{SiC}$ як конструкційних матеріалів для застосування у ядерної енергетиці $\epsilon$ високотемпературні властивості, висока щільність та зменшена активація нейтронів. Використання радіаційностійких матеріалів є суворою вимогою до функціонування безпечної та екологічно чистої енергетичної системи. Структурна стабільність кераміки при опроміненні до температури 1273 К також дуже важлива для застосування в ядерної енергетиці. Матриці $\mathrm{SiC}$, леговані добавками $\mathrm{Cr}$ та $\mathrm{Si}$, були виготовлені методом високошвидкісного гарячого пресування. Вміст добавок складав від 0,5 до $3 \%$ мас. Мікроструктурні характеристики кераміки карбіду кремнію були проаналізовані методом рентгенівської дифракції (XRD), сканувальної електронної мікроскопії (SEM), енерго-дисперсійної рентгенівської спектроскопії (EDX) та методів інфрачервоної спектроскопії (IЧ). Результати тріщиностійкості в умовах навантаження виявили незначну кількість тріщин у кераміці $\mathrm{SiC} з$ добавками $\mathrm{Cr}$ до і після процесу опромінення. Крім того, було продемонстровано, що зразки $\mathrm{SiC}$ з легуючими добавками $\mathrm{Cr}$ i $\mathrm{Si}$ мають високі механічні параметри при $\gamma$-опроміненні. Міцність кераміки зростає з утворенням однорідної та дрібнозернистої структури. Проаналізовано модифікацію фазового складу та механічних властивостей кераміки $\mathrm{SiC}$ з добавками $\mathrm{Cr}$ i $\mathrm{Si}$ при $\gamma$-опроміненні для подальшого розвитку матеріалів, що стійкі до випромінювання, та матриць для іммобілізації радіоактивних відходів.

КЛЮЧОВІ СЛОВА: карбід кремнію, опромінення, фізико-механічні властивості, іммобілізація ядерних відходів, мікроструктурні характеристики.

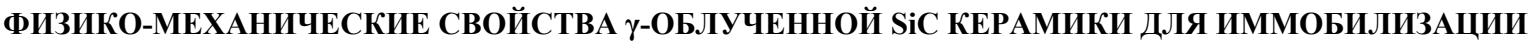 РАДИОАКТИВНЫХ ОТХОДОВ}

К.В. Лобач ${ }^{1}$, С.Ю. Саенко ${ }^{1}$, В.А. Шкуропатенко ${ }^{1}$, В.Н. Воеводин ${ }^{1,3}$, А.В. Зыкова ${ }^{1}$,

Е.П. Березняк ${ }^{1}$ Ю.С. Ходырева ${ }^{1}$, С.М. Быканов ${ }^{2}$, А.А. Быков ${ }^{2}$, Л.Л. Товажнянский ${ }^{2}$

${ }^{1}$ ННЦ Харьковский физико-технический институт, 61108, Харьков, Украина

${ }^{2}$ НТУ «Харьковский политехнический институт», 61002, Харьков, Украина

${ }^{3}$ Харьковский национальный университет имени В.Н. Каразина, 61022, Харьков, Украина

Интерес к керамике из карбида кремния (на основе $\mathrm{SiC}$ ) и композитам в качестве матричного материала для иммобилизации ядерных отходов повышается. Долгосрочная химическая и радиационная стойкость $\mathrm{SiC}$ являются важными факторами для 
иммобилизации радионуклидов. Преимуществами керамики на основе $\mathrm{SiC}$ в качестве конструкционных материалов для применения в ядерной энергетике являются высокотемпературные свойства, высокая плотность и уменьшенная активация нейтронов. Использование радиационностойких материалов является строгим требованием к функционированию безопасной и экологически чистой энергетической системы. Структурная стабильность керамики при облучении до температуры 1273 К, также очень важна для применения в ядерной энергетике. Матрицы $\mathrm{SiC}$, легированные добавками Cr и $\mathrm{Si}$, были изготовлены с использованием метода высокоскоростного горячего прессования. Содержание добавок находилось в диапазоне от 0,5 до 3 мас.\%. Микроструктурные характеристики керамики из карбида кремния были проанализированы с помощью рентгеновской дифракции (XRD), сканирующей электронной микроскопии (SEM), энергодисперсной рентгеновской спектроскопии (EDX) и инфракрасной спектроскопии (ИК). Результаты трещиностойкости в условиях индентирования показали небольшое количество трещин в керамике $\mathrm{SiC}$ с добавками $\mathrm{Cr}$ до и после процесса облучения. Кроме того, было продемонстрировано, что образцы $\mathrm{SiC}$ с легирующими добавками $\mathrm{Cr}$ и $\mathrm{Si}$ имеют высокие механические параметры при $\gamma$-облучении. Прочность керамики растет с образованием однородной и мелкозернистой структуры. Проанализирована модификация фазового состава и механических свойств $\mathrm{SiC}$-керамики с добавками $\mathrm{Cr}$ и $\mathrm{Si}$ при $\gamma$ облучении для дальнейшего развития радиационно-стойких материалов и матриц для иммобилизации радиоактивных отходов.

КЛЮЧЕВЫЕ СЛОВА: карбид кремния, облучение, физико-механические свойства, иммобилизация ядерных отходов, микроструктурные характеристики.

SiC-based ceramics and composites possess superior properties, such as high corrosion resistance, excellent chemical and thermal shock stability, high mechanical strength, thermal expansion and small neutron absorption crosssection [1-3]. Such properties are very attractive for further operating under extreme environmental conditions, in particular, as matrix material for water-cooled and fusion power reactors, for the nuclear fuel as a cladding material, and us protective form for radioactive waste immobilization [4-6].

Advantages of SiC-based ceramics and composites as structural materials in fusion applications are the hightemperature properties and stability, density and reduced neutron activation. The use of activation materials (LAMs) is a strong requirement for safe and environmentally beneficial energy system. The $\mathrm{SiC}$ ceramics dimensional stability under irradiation for temperatures up to $1273 \mathrm{~K}$ [7] is also very important for fusion power applications.

The interest in $\mathrm{SiC}$ matrix material for nuclear waste immobilization is grown up. SiC ceramics and composites have been proposed as an inert matrix for the burning or transmutation of long-lived fission products and minor actinides from fuel cycle reprocessing. Nuclear waste is highly radioactive and toxic for hundreds of thousands of years. The basis of light water reactor (LWRs) fuel cycle is storing of processing fuels into geologically stable repositories in specially designed canisters, where the radioactive materials can decay for long times, with minimal release to the environment. [8,9]. In all proposed deep-burn fuel cycle involving tristructural isotropic (TRISO) fuel, where $\mathrm{SiC}$ is the primary barrier to fission product release, high burn up reduces the need for reprocessing, and the high-burn up TRISO fuel could be placed directly in a geologic repository. TRISO fuels, incorporated in a dense SiC matrix has been proposed for both transuranic waste destruction and as a potential fuel for light water reactors [9].

The long-term chemical durability and radiation resistance of $\mathrm{SiC}$ are important factors for radionuclides immobilization. Due to the low induced activation, $\mathrm{SiC}$ ceramics were proposed as structural components for long-term geologic disposal of the low-level or intermediate level waste. In operating conditions, energetic particles may alter $\mathrm{SiC}$ retention capability for the fission products, producing atomic displacements. The resulting microstructural changes may eventually modify the properties of the SiC ceramics [10].

The oxidation behaviour of $\mathrm{SiC}$ in water vapour containing environments was examined in details [11]. $\mathrm{SiC}$ exhibits exceptional oxidation resistance in water vapour up to $1700^{\circ} \mathrm{C}$. The oxidation of $\mathrm{SiC}$ has been studied in a variety of gaseous environments. Of particular interest for the nuclear industry is oxidation resistance in a water/steam environment [12]. It has been shown, that radiation significantly affects important material properties [13]. Recent studies on the corrosion rates of unirradiated and irradiated $\mathrm{SiC}$ in different simulated ground waters over a range of temperatures revealed no significant long-term effect of irradiation on corrosion behaviour [14]. The mechanisms and rates of corrosion for $\mathrm{SiC}$ in different aqueous media under conditions relevant to geologic repositories have also been reported [15], and indicated that the radiotoxicity of spent TRISO fuel is at least four orders of magnitude lower than for current spent light water reactor fuel.

Radiation effects induced by neutrons at high temperature were widely studied. Microstructural evolution over a large range of temperatures and swelling [16] were the main investigated topics. However, the gamma radiation influence on $\mathrm{SiC}$ ceramic is of great interest due to an action of gamma radiation as main source of the effect on the protective matrices during wastes immobilization process.

At the process of $\mathrm{SiC}$ exposure to high-temperature, and extreme radiation environments, microstructural evolution and micro cracking may occur. During $\mathrm{SiC}$ matrix exposure to beta and gamma radiation from fission product decay irradiation-induced amorphization took place. The critical temperature for amorphization from high flux electron beams was about 300-340 K depending on SiC structure modification [17-19].

The retention capability of $\mathrm{SiC}$ for the typical fission product, particularly when it is submitted to irradiationinduced structural modifications was studied. The evolution of a disorder with the ion fluence and the cumulative dose in dpa ('displacements per atom') was calculated [20]. It appears that total disorder (i.e., amorphization) is achieved at $0.25 \mathrm{dpa}$. In previous studies, the structural modifications induced by the implantation of a typical fission product iodine 
(I) into silicon carbide were examined. This result is in good agreement with previous investigations using other ion species [21] and demonstrate that $\mathrm{SiC}$ is a very easily amorphizable material by low energy ion implantation at room temperature while it can hardly be disordered by ion bombardment at elevated temperatures. For inert matrix fuels, SiC ceramics demonstrate phase compounds with reasonably high radiation stability to high temperatures for different fissile species [22].

The good corrosion and radiation resistances exhibited by the carbides are due to the unique combination of high hardness and fracture toughness. The bulk mechanical properties and stability of carbides are strongly affected by their composition and microstructural parameters [23, 24]. The different additives, such as oxides, Si, B, and transitional metals of IV-VI subgroups, as sintering activators, were added to improve the mechanical properties of SiC ceramics. The effect of additives on the ceramic sintering mechanism relates to its content and uniformity. The uniform distribution of additives is beneficial for improving the densification and microstructure formation during the sintering procedure [25-28].

The aim of the present study was the studying the influence of $\gamma$-irradiation on surface and physic-mechanical properties of the $\mathrm{SiC}$ ceramics modified by additives of $\mathrm{Cr}$ and $\mathrm{Si}$.

\section{MATERIALS AND METHODS}

The highly dispersed powders were used as alloying additives for producing ceramics based on silicon carbide ( $\mathrm{SiC}$ ): $\mathrm{SiC}$ powders of the grade $440 \mathrm{NDP}$ (Superior Graphite Co) with a predominant particle size $0.44 \mu \mathrm{m}$ were chosen as primary material, and powders of $\mathrm{Si}$, and $\mathrm{Cr}$, with a predominant particle size $<3 \mu \mathrm{m}$ as additives. Mixing of the initial powders was carried out in a planetary mono-mill "Pulverisette 6" (Germany) in isopropyl alcohol medium with a rotation speed of 300 rpm during 3 hours.

Forming and sintering of the samples were made by the method of high-speed hot pressing in vacuum in a graphite die. The equipment was developed in NSC KIPT in the framework of joint collaboration project (STCU P-154) with Argon National Laboratory and Superior Graphite Co (USA). The optimum process parameters were previously determined and described [29]: sintering temperature $2050{ }^{\circ} \mathrm{C}$, pressure $40 \mathrm{MPa}$ and holding time 30 minutes. The samples size was $25 \times 25 \times 4 \mathrm{~mm}$. Finishing surface treatment and polishing of SiC ceramics were made by series of diamond pastes graded from $28 / 20,7 / 5,5 / 3,3 / 2$. As a result of surface polishing with low rates diamond pastes treatment, $25-75 \mu \mathrm{m}$ of defect surface layers were removed to a high degree of mechanical tests accuracy. The open porosity and density of the samples were determined by hydrostatic weighing method.

The diffractometry was carried out using a DRON-4-07 X-ray diffractometer in copper $\mathrm{Cu}-\mathrm{K} \alpha$ radiation using a Ni selectively absorbing $\beta$-filter. The diffracted radiation was detected by a scintillation detector.

The absorption spectra in the IR range were recorded by IR spectrophotometer IRS-29 (LOMO) in the KIPT NSU. The spectra detection was made in the spectral range $4000-400 \mathrm{~cm}^{-1}$ (mean infra red area).

$\mathrm{SiC}$ samples were irradiated by bremsstrahlung obtained in Electron Linear Accelerator (ElA) with beam energy up to $10 \mathrm{Mev}$, current $800 \mathrm{~mA}$, dose rate $1.1 \mathrm{kGy} / \mathrm{h}$ up to dose $10 \mathrm{kGy}$. To realize the conditions of external $\gamma$ irradiation effect of the SiC specimens, the bremsstrahlung of the ELA was used. Irradiation scheme is shown on Fig.1.

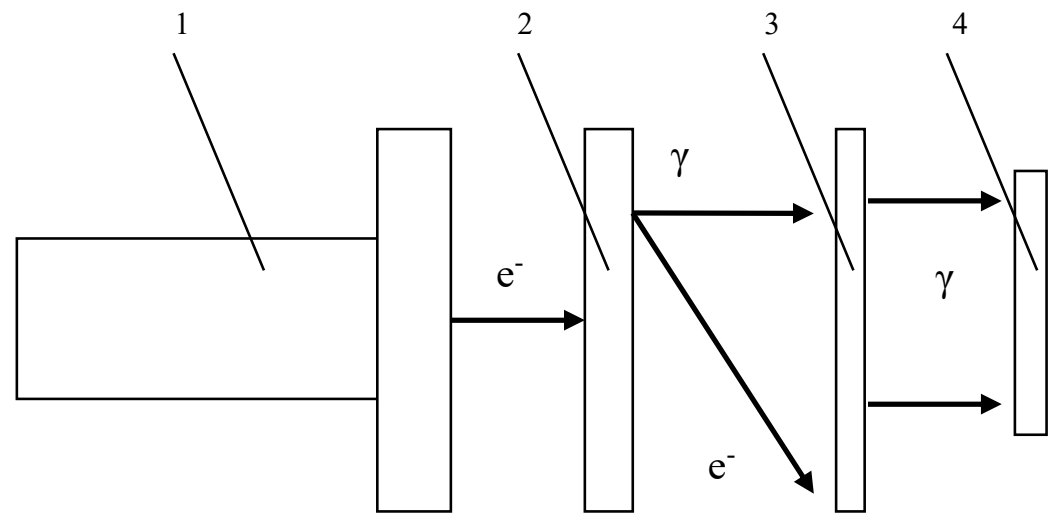

Fig. 1. Scheme of $\gamma$-irradiation in electron accelerator: $\mathrm{e}^{-}$- electrons, 1 - electron accelerator, 2 - Ta-converter,

3 - filter for electrons and neutrons, $4-\mathrm{SiC}$ specimen

The hardness tests of $\mathrm{SiC}$ ceramic samples before and after $\gamma$-irradiation process were made on a AMH-3 microhardometer by indentation of a four-sided 136-degree Vickers diamond pyramid. The optimal load value was chosen: $9.8 \mathrm{~N}$. The hardness calculations were carried out according to the standard procedure with the measurement of the diagonals of the print: 


$$
\mathrm{H}_{\mathrm{V}}=\mathrm{P} / \mathrm{d}^{2}
$$

where $\mathrm{H}$ is hardness, $\mathrm{P}$ is the load on the indenter, $\mathrm{d}^{2}$ is the square of the diagonals of the indentor's print.

The measurements of fracture toughness of ceramic carbide are complicated because of high brittleness of these materials. Estimation of fracture toughness values was made at $9.8 \mathrm{~N}$ load conditions. The equations of fracture toughness of ceramic brittle materials, which are in a good agreement with experimental data were formulated by Evans, Charles and Wilshaw [30] and by Niihara [31]. Equations for fracture toughness coefficient $\left(\mathrm{K}_{1 \mathrm{C}}\right)$ calculation were obtained by Niihara semi empiric dependence, commonly used for brittle ceramics [31]:

$$
\mathrm{K}_{1 \mathrm{c}}=\left(0,035 \mathrm{H}_{\mathrm{v}} \mathrm{a}\right)\left(\mathrm{E} \phi / \mathrm{H}_{\mathrm{v}}\right)^{2 / 5} / \phi \mathrm{L}^{0.5}
$$

where a is the half-diagonal of the indentor's print, $\mathrm{Hv}$ is the hardness of the material, and $\mathrm{L}$ is the length of the radial crack, E is Young modulus, $\phi-$ is the constraint factor $(\approx 3)$

The microstructure and morphology of the samples were studied by JEM-700F scanning electron microscope. The Energy-dispersive X-ray spectroscopy (EDS) method with a high-energy electron beam was used for determination of the elements and distribution in the $\mathrm{SiC}-\mathrm{Si}$ and $\mathrm{SiC}-\mathrm{Cr}$ samples.

\section{RESULTS AND DISCUSSION}

The physical properties and phase composition of SiC ceramic samples with/without alloying additives obtained at the same technological parameters as previously reported [28] were presented in Table 1.

Table 1.

Properties and crystalline phases of the SiC samples

\begin{tabular}{|l|l|l|l|}
\hline Ceramic composition & $\mathrm{SiC}$ & $\begin{array}{l}\mathrm{SiC}+ \\
0.5 \% \mathrm{Cr}+0.15 \% \mathrm{C}\end{array}$ & $\begin{array}{l}\mathrm{SiC}+ \\
1.0 \% \mathrm{Si}+0.3 \% \mathrm{C}\end{array}$ \\
\hline Open porosity, $\%$ & 0 & $0-1$ & $0-1$ \\
\hline Density $\mathrm{g} / \mathrm{cm}^{3}$ & 3.19 & 3.16 & 3.18 \\
\hline Relative density, $\rho, \%$ & $99.4 \pm 0.75$ & $97.8 \pm 0.75$ & $99.7 \pm 0.75$ \\
\hline Phase composition & $\mathrm{SiC}-6 \mathrm{H} 99 \%$ & $\mathrm{SiC}-6 \mathrm{H}-95.5 \%$ & $\mathrm{SiC}-6 \mathrm{H}-83.8 \%$ \\
& $\mathrm{C}-1 \%$ & $\mathrm{SiC}-4 \mathrm{H}-2.8 \%$ & $\mathrm{SiC}-4 \mathrm{H}-16.2 \%$ \\
\hline
\end{tabular}

Analysis of the data given in Table 1 indicates that a slight decrease in the relative density is observed in SiC ceramic samples with alloying additives: up to $97.8 \%(\mathrm{Cr})$.

$\mathrm{X}$-ray diffraction analysis of the samples revealed the presence of one phase $\alpha$-SiC of polytype $-\mathrm{SiC}-6 \mathrm{H}$ with hexagonal lattice, whereas the introduction of the alloying additives leads to structural changes and the formation of a second $\alpha$-SiC polytype of silicon carbide $-\mathrm{SiC}-4 \mathrm{H}$ in different weight contents (Table 1, Fig. 2).
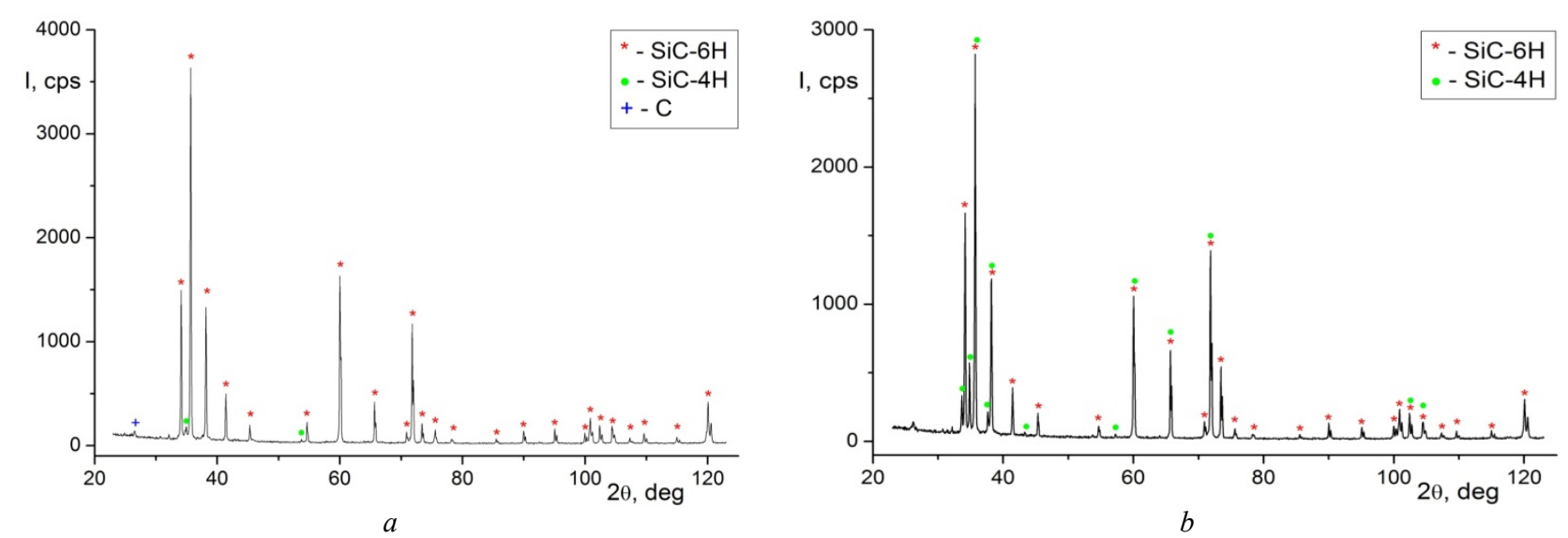

Fig.2. XRD patterns of the samples:

$\mathrm{a}-\mathrm{SiC}+0.5 \% \mathrm{Cr}+0.15 \% \mathrm{C}, \mathrm{b}-\mathrm{SiC}+1.0 \% \mathrm{Si}+0.3 \% \mathrm{C}$

Electron microscope images of the fractured cross-sections of the samples $\mathrm{SiC}+1.0 \% \mathrm{Si}+0.3 \% \mathrm{C}$ and $\mathrm{SiC}+$ $0.5 \% \mathrm{Cr}+0.15 \% \mathrm{C}$ were presented (Fig. 3,4). The structure of SiC sample with the Si additives demonstrates a very dense and uniformly fine-grained structure $(99.7 \%$ of the theoretical values). The grain sizes were in the range $0.3-2.2$ $\mu \mathrm{m}$ with a predominant grain size of $1.5 \mu \mathrm{m}$. 


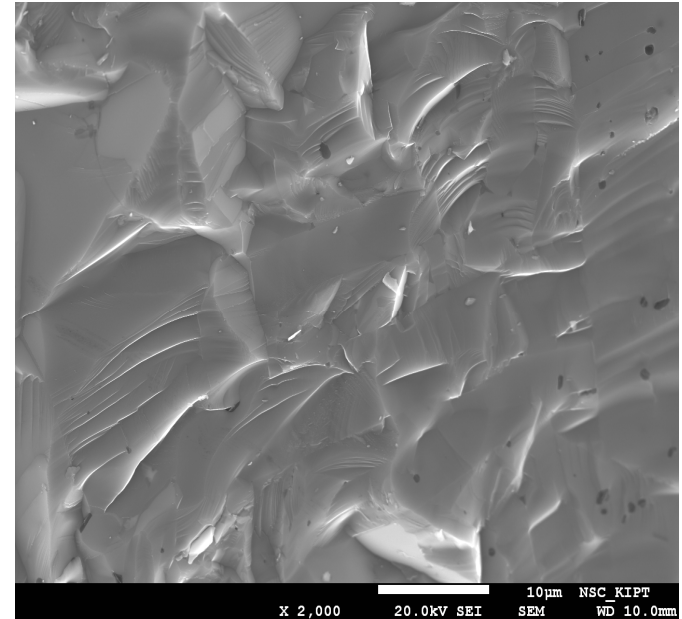

a

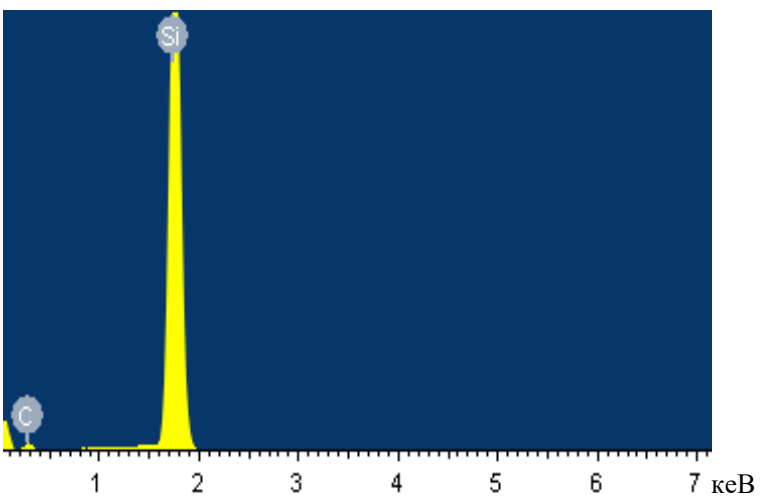

b

Fig. 3. SEM images (a) and EDX spectra (b) of $\mathrm{SiC}+1.0 \% \mathrm{Si}+0.3 \% \mathrm{C}$ sample

Analysis of $\mathrm{SEM} / \mathrm{EDX}$ results for $\mathrm{SiC}+0.5 \% \mathrm{Cr}+0.15 \% \mathrm{C}$ sample demonstrate that $\mathrm{Cr}$ adding leads to inclusions formation, probably of $\mathrm{Cr}_{\mathrm{n}} \mathrm{C}_{\mathrm{x}}$ chromium carbide types. According to small amount of $\mathrm{Cr}$, the presence of chromium carbide phase formation was not detected on XRD patterns of the ceramic samples (Fig. $4 \mathrm{a}$ ).

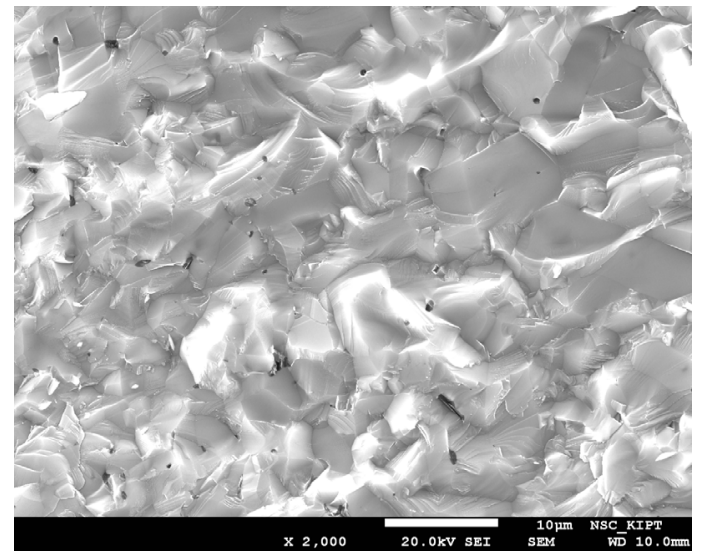

a

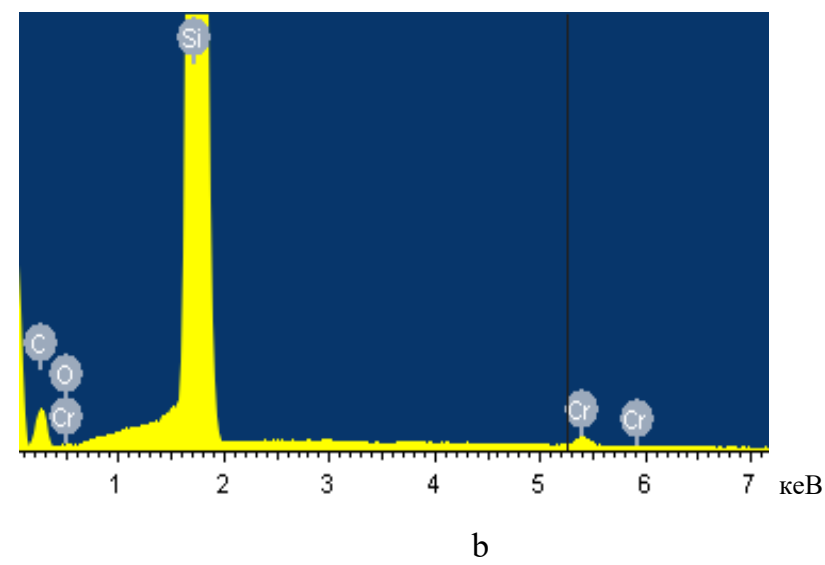

b

Fig. 4. SEM images (a) and EDX spectra (b) of $\mathrm{SiC}+0.5 \% \mathrm{Cr}+0.15 \% \mathrm{C}$ sample

The main approach to enhance the mechanical properties and fracture toughness is sintering of materials with dense and uniform grain microstructure. The strength of ceramics increases with the decrease of grain size and porosity. The evolution of phase composition and mechanical properties of SiC ceramic under $\gamma$-irradiation and irradiationinduced structural modifications was studied.

The hardness tests of $\mathrm{SiC}$ ceramic samples were made by indentation under load condition $9.8 \mathrm{~N}$ before and after irradiation process. Cracks appear on all samples, except the sample with the $\mathrm{Cr}$ additives before and after dose $\gamma$ irradiation (Fig.5 a, b, e). This fact indicates that the crack resistance and fracture toughness coefficient were not principally changed before and after irradiation process, which is also confirmed by the calculations carried out according to formula (2).

Table 2 shows the values for hardness and fracture toughness calculations before and after $\gamma$-irradiation process. As can be seen from the obtained data, hardness and fracture toughness values are not principally changed for both samples with additive $\mathrm{Cr}$ and $\mathrm{Si}$. SiC samples without additives produced by High-Speed Hot Pressing Method show high density and microhardness parameters. The fracture toughness parameters demonstrate the values from $\mathrm{K}_{1 \mathrm{c}}=4.5$ $\mathrm{MPa} \cdot \mathrm{m}^{1 / 2}-4.2 \mathrm{MPa} \cdot \mathrm{m}^{1 / 2}$ for $\mathrm{SiC}$ ceramic samples to $\mathrm{K}_{1 \mathrm{c}}=5.6 \mathrm{MPa} \cdot \mathrm{m}^{1 / 2}-5.4 \mathrm{MPa} \cdot \mathrm{m}^{1 / 2}$ for SiC samples with $\mathrm{Cr}$ additives, and $\mathrm{K}_{1 \mathrm{c}}=4.4 \mathrm{MPa} \cdot \mathrm{m}^{1 / 2}-4.2 \mathrm{MPa} \cdot \mathrm{m}^{1 / 2}$ for $\mathrm{SiC}$ samples with $\mathrm{Si}$ additives, before and after $\gamma$-irradiation process correspondently.

Previously was reported, that dense and uniform SiC ceramics demonstrate high mechanical parameters: micro hardness $24 \mathrm{GPa}[32,33]$ and fracture toughness coefficient $\mathrm{K}_{1 \mathrm{c}}=5 \mathrm{MPa} \cdot \mathrm{m}^{1 / 2}$ [32]. At present study, SiC ceramic samples with $\mathrm{Si}, \mathrm{Cr}$ and without additives also show high mechanical parameters: micro hardness $29.8 \mathrm{GPa}$ and fracture toughness coefficient $\mathrm{K}_{1 \mathrm{c}}=4.5 \mathrm{MPa} \cdot \mathrm{m}^{1 / 2}$. Furthermore, a dose $\gamma$-irradiation process did not significantly change the 
mechanical properties of $\mathrm{SiC}$ ceramic with both $\mathrm{Si}$ and $\mathrm{Cr}$ additives, only slight decrease of fracture toughness coefficient up to $5.4 \mathrm{MPa} \cdot \mathrm{m}^{1 / 2}$ and $4.2 \mathrm{MPa} \cdot \mathrm{m}^{1 / 2}$ was detected.
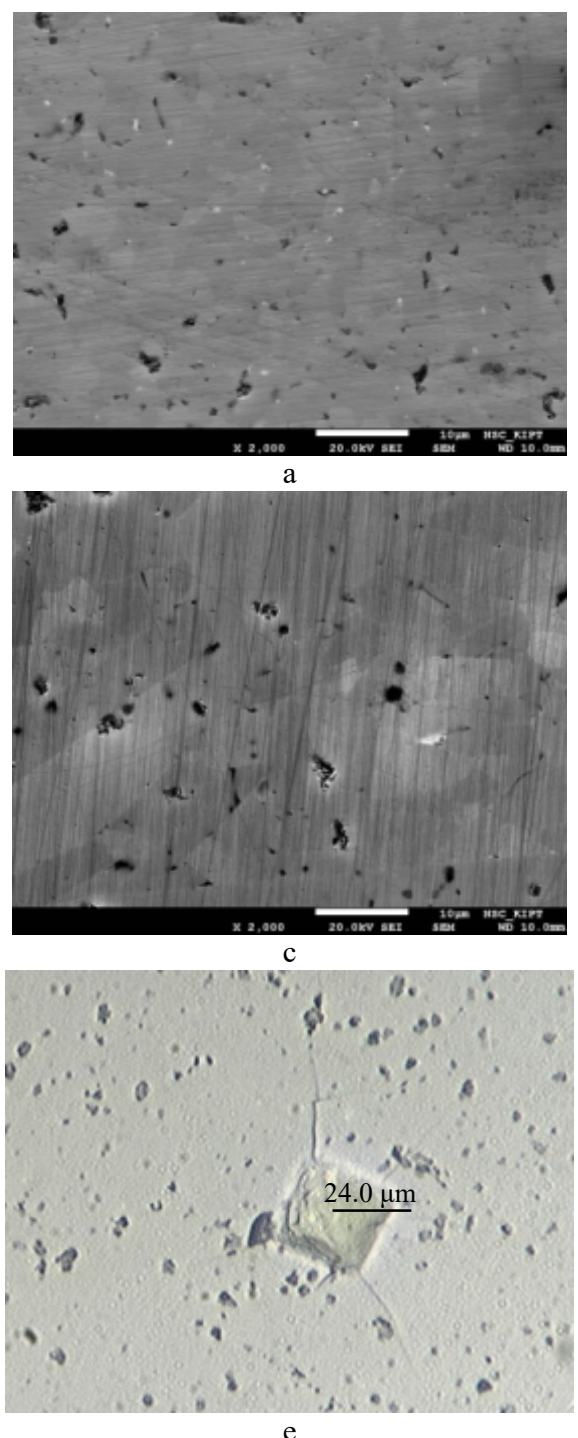
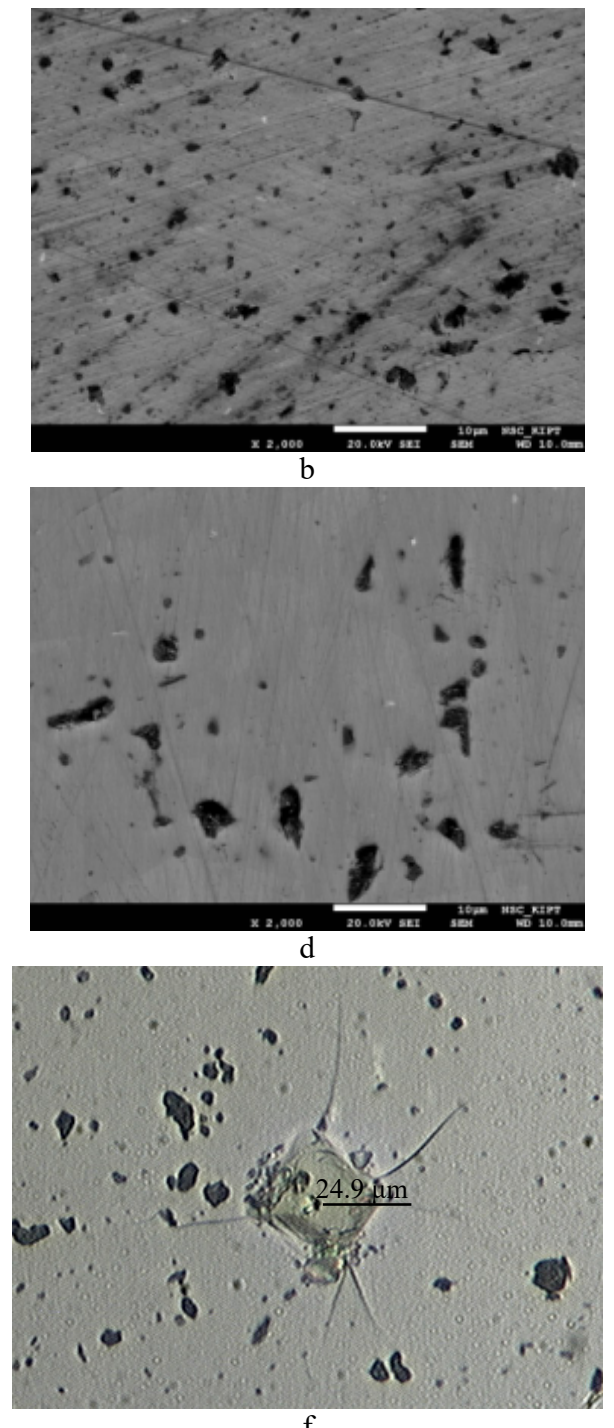

f

Fig. 5. Images of the ceramic surface before $(a, c)$ and $(b, d)$ after $\gamma$-irradiation process and indentor's print $(\mathrm{e}, \mathrm{f})$ after irradiation:

$\mathrm{a}, \mathrm{b}, \mathrm{e}-\mathrm{SiC}+0.5 \% \mathrm{Cr}+0.15 \% \mathrm{C} ; \mathrm{c}, \mathrm{d}, \mathrm{f}-\mathrm{SiC}+1.0 \% \mathrm{Si}+0.3 \% \mathrm{C}$

Table 2.

Hardness and fracture toughness

\begin{tabular}{|l|c|c|c|}
\hline \multicolumn{1}{|c|}{ Ceramic material } & $\begin{array}{c}\text { Load } \mathrm{P} \\
\mathrm{N}\end{array}$ & $\begin{array}{c}\text { Hardness } \mathrm{HV}, \mathrm{GPa} \\
\text { before / after } \gamma \text {-irradiation process }\end{array}$ & $\begin{array}{c}\text { Fracture toughness } \mathrm{K}_{1 \mathrm{c}}, \mathrm{MPa} \cdot \mathrm{m}^{1 / 2} \\
\text { before / after } \gamma \text {-irradiation process }\end{array}$ \\
\hline $\mathrm{SiC}$ & 9.81 & $29.8 / 29.8$ & $4.5 / 4.2$ \\
\hline $\mathrm{SiC}+0.5 \% \mathrm{Cr}+0.15 \% \mathrm{C}$ & 9.81 & $33.4 / 32.2$ & $5.6 / 5.4$ \\
\hline $\mathrm{SiC}+1.0 \% \mathrm{Si}+0.3 \% \mathrm{C}$ & 9.81 & $30.9 / 29.9$ & $4.4 / 4.2$ \\
\hline
\end{tabular}

IR spectrum of SiC samples without additives produced by High-Speed Hot Pressing Method demonstrates peaks of 580, 650,820, 935 and $990 \mathrm{~cm}^{-1}$, related to the Si-C vibrations at the silicon carbide structure with hexagonal crystal structure. In addition, the intensive absorption bands were detected correlated to stretching and deformation vibrations of

Si-O in tetrahedral $\mathrm{SiO}_{4}$ quartz structure: 460, 510, 690, 780, 800, 1080 and $1160 \mathrm{~cm}^{-1}$ (Fig. 6, curve 1) [34, 35]. The $\mathrm{SiO}_{2}$ formation can occur as a result of sample oxidation during the heat treatment process. The absorbed water band of $3450 \mathrm{~cm}^{-1}$ also was observed.

After $\gamma$-irradiation process up to $10^{4} \mathrm{~Gy}$ dose any visible changes at the absorbed spectra were not detected. An intensity of band at the vibration range of $\mathrm{O}-\mathrm{H}\left(3430 \mathrm{~cm}^{-1}\right)$ was slightly decreased. Thus, $\gamma$-irradiation process up to $10^{4}$ Gy dose had no effect on the phase composition and crystal structure of SiC ceramic samples. 
An analysis of IR absorption spectra of SiC samples before and after irradiation process demonstrated no principal distinctions between samples with/without $0.5 \% \mathrm{Cr}$ и $\mathrm{Si}$ additives.

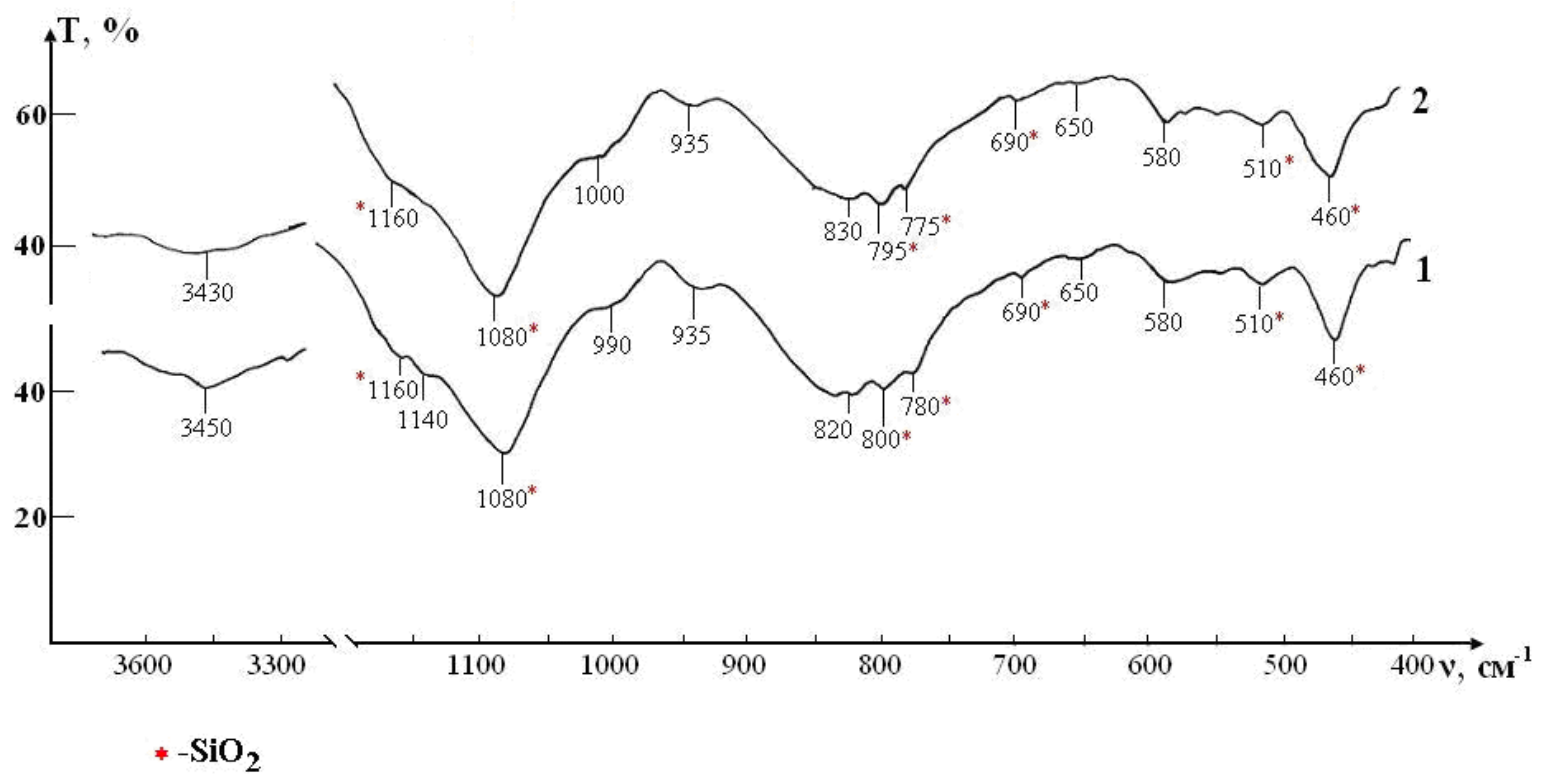

Fig. 6. IR absorption spectra of $\mathrm{SiC}$ samples after sintering:

curve 1 - initial $\mathrm{SiC}$, curve 2 - $\mathrm{SiC}$ after $\gamma$-irradiation process up to $10^{4} \mathrm{~Gy}$ dose

\section{CONCLUSIONS}

Sintering process by High-Speed Hot Pressing Method leads to the fine-grained structure formation and increase of the fracture toughness of ceramics. The hardness and crack resistance of $\mathrm{SiC}$ ceramics with $\mathrm{Cr}$ and $\mathrm{Si}$ additives were not principally changed under $\gamma$-irradiation process. The results of microcracking under indentation conditions were revealed the lack of cracks in the $\mathrm{SiC}$ ceramics with $\mathrm{Cr}$ additives before and after irradiation process. In addition, it was demonstrated that samples of $\mathrm{SiC}$ with alloying additives $\mathrm{Cr}$ and $\mathrm{Si}$ possess high mechanical parameters under $\gamma$ irradiation process: microhardness $-32.2-29.9 \mathrm{GPa}$, fracture toughness coefficient $\mathrm{K}_{1 \mathrm{C}}=5.4-4.2 \mathrm{MPa} \cdot \mathrm{m}^{1 / 2}$, respectively. The strength of ceramics increases with the uniform and fine-grained structure formation. The analysis of IR absorption spectra demonstrates that any phase composition and crystal structure changes were not observed after $\gamma$ irradiation process. The samples sintered with $\mathrm{Cr}$ and $\mathrm{Si}$ additives demonstrate good radiance resistance and high mechanical properties under $\gamma$-irradiation up to absorption dose of $10^{4} \mathrm{~Gy}$, which confirms the advantages of alloying additives using. $\mathrm{SiC}$ ceramics with $\mathrm{Cr}$ and $\mathrm{Si}$ additives are promising candidates for further nuclear applications as radiation resistant materials to manufacture protective matrices for radioactive wastes immobilization.

\section{ORCID IDs}

K. Lobach (D) https://orcid.org/0000-0002-9838-2259, S. Sayenko (D) https://orcid.org/0000-0002-2598-3598,

V. Shkuropatenko (i) https://orcid.org/0000-0003-2618-0858, V. Voyevodin (i) https://orcid.org/0000-0003-2290-5313,

A. Zykova (D) https://orcid.org/0000-0001-6390-8161, E. Bereznyak (D) https://orcid.org/0000-0002-9416-2291,

L. Tovazhnyanskyy (D) https://orcid.org/0000-0002-9000-3824

\section{REFERENCES}

[1]. L.L. Snead, R.H. Jones, A. Kohyama and P. Fenici, J. Nucl. Mater. 26, 233-237 (1996).

[2]. Y. Katoh, L.L. Snead, I. Szlufarska and W.J Weber, Current Opinion in Solid State and Materials Science. 16. 143-152 (2012).

[3]. Y. Katoh, L.L. Snead, T. Cheng, C. Shih, W.D. Lewis, T. Koyanagi and T. Hinoki, J. Nucl. Mater. 448, 497-511 (2014).

[4]. C.H. Henager, Y. Shin, Y. Blum, L.A. Giannuzzi, B.W. Kempshall and S.M. Schwarz, J. Nucl. Mater. 1139, $367-370$ (2007).

[5]. R.A. Verrall, M.D. Vlajic and V.D. Krstic, Journal of Nuclear Materials. 274, 54-60 (1999).

[6]. B.A. Pint, K.A. Terrani, M.P. Brady, T. Cheng and J.R. Keiser, J. Nucl. Mater. 440, 420-427 (2013).

[7]. P. Fenici, A.J. Frias Rebelo, R.H. Jones, A. Kohyama and L.L. Snead, Journal of Nuclear Materials. 258-263, 215-225 (1998).

[8]. K.H. Sarma, J. Fourcade, S-G. Lee and A.A. Solomon, J. Nucl. Mater. 352, 324-333 (2006).

[9]. J.J. Powers, B.D. Wirth, J. Nucl. Mater. 405, 74-82 (2010).

[10].Y. Katoh, K. Ozawa, C. Shih, T. Nozawa, R.J. Shinavski, A. Hasegawa and L.L. Snead, J. Nucl. Mater. 448, 448-476 (2014).

[11].P.F. Tortorelli, K.L. More, J. Am. Ceram. Soc. 86, 1249-1255 (2003).

[12].E.J. Opila, J. Am. Ceram. Soc. 82(3), 625-636 (1999).

[13].M. Herrmann, W. Lippmann and A. Hurtado, J. Nucl. Mater. 443, 458-466 (2013).

[14].J. Fachinger, M. den Exter, B. Grambow, S. Holgersson, C. Landesman and M. Titov, Nucl Eng Des. 236, 543-554 (2006).

[15].J.L. Peterson, M.L. Dunzik-Gougar, Progr. Nucl. Energy. 53, 278-284 (2011).

[16].S. Sorieul, J-M. Costantini, L. Gosmain, L. Thome and J-J. Grob, Journal of Physics: Condensed Matter. 18, $5235-5251$ (2006).

[17].T. Cheng, R.H. Baney and J. Tulenko, J. Nucl. Mater. 411, 126-130 (2011). 
[18].W.J. Weber, L. Wang, Y. Zhang, W. Jiang and I-T Bae, Nucl. Instrum. Methods Phys. Res. B. 266, 2793-2796 (2008).

[19].L.L. Snead, Y. Katoh, A. Kohyama, J.L. Bailey, N.L. Vaughn and R.A. Lowden, J. Nucl. Mater. 283, 551-555 (2000).

[20].C.J. McHargue, J.M. Williams, Nucl. Instr. and Meth. B. 80-81, 889-894 (1993).

[21]. M.G. Grimaldi, L. Calcagno, P. Musumeci, N. Frangis and J. Van Landuyt, J. Appl. Phys. 81, 7181-7185 (1997).

[22]. A. Audren, A. Benyagoub, L. Thome and F. Garrido, Nuclear Instruments and Methods in Physics Research B. 257, 227-230 (2007).

[23].J.H. She, K. Ueno, Materials Research Bulletin. 34(10-11), 1629-1636 (1999).

[24].Z.H. Huang, D.C. Jia, Ceramics International. 29, 13-17 (2003).

[25].V.A. Izhevsikyi, L.A. Genova, International Journal of Refractory Metal \& Hard Materials. 19, 407-409 (2001).

[26].R.P. Jensen, E.W. Luecke, Materials Science and Engineering A. 282, 109-114 (2000).

[27].Y.W. Kim, J.Y. Kim, Journal of the European Ceramic Society. 20, 945-949 (2000).

[28].E. Liden, E. Carlstrom, Journal of the American Ceramic Society. 78(7), 1761-1768 (1995).

[29].K. Lobach, Ye. Svitlychnyi, S. Sayenko, V. Voyevodin, A. Zykova, H. Ghaemi, M. Szkodo, G. Gajowiec, M. Kmiec and M. Antoszkiewicz, Problems of atomic science and technology. 108(2), 97-102 (2017).

[30].A.G. Evans, E.A. Charles, Journal of the American Ceramic Society. 59, 371-372 (1976).

[31].K. Niihara, J. Mater. Sci. Lett. 2, 221-223 (1983).

[32].J. Wade, P. Claydon and H. Wu, in: Ceramic Engineering and Science Proceedings. Mechanical Properties and Performance of Engineering Ceramics and Composites IX. Vol. 35(2). Edited by Dileep Singh and Jonathan Salem (Wiley, Weinheim, 2014), pp. 91-100, doi: 10.1002/9781119031192.ch10.

[33].D.O., Moskovskikh Y. Song, S. Rouvimov, A.S. Rogachev and A.S. Mukasyan, Ceramics International. 42, 12686-12693 (2016).

[34].Van der Marel and H. Beutelspacher, Atlas of infrared spectroscopy of clay minerals and their admixtures, (Elsevier, Amsterdam, 1976), p. 396.

[35].T. Merle-Mejean, E., Abdelmounm and P. Quintard, Journal of Molecular Structure. 349, 105-108 (1995). 